Krpalek, P., Krpalkova Krelova, K., Berkova, K. (2018). The Importance of Metacognitive Strategies for Building Competitive Business Competencies. Journal of Competitiveness, 10(3), 69-85. https://doi. org/10.7441/joc. 2018.03 .05

\title{
THE IMPORTANCE OF METACOGNITIVE STRATEGIES FOR BUILDING COMPETITIVE BUSINESS COMPETENCIES
}

\section{- Pavel Krpalek, Katarina Krpalkova Krelova, Katerina Berkova}

\begin{abstract}
The aim of this study is to verify and evaluate experimentally the effect of using activating methods and the related application of metacognitive learning strategies in case studies. The research sample consisted of 220 students, 16-17 years old. The experiment was chosen as the basic research method. The authors' research focuses first on building a case study. This was subsequently verified experimentally in the second research phase, and its effect on the development of higher cognitive dimensions was evaluated. Relevant research tools were developed, including a case study adapted to each age group of students with a focus on relevant educational content and two non-standardized professional tests in the form of a post-test that was uniformly designed for the experimental and control group to determine the range of effects at the level of development of lower and higher-order thinking processes that the implemented methods can produce. The tests took into account the age of students, content and cognitive difficulty. The non-parametric Mann-Whitney u-test was chosen to verify null hypotheses at $5 \%$ significance. The results indicate that the application of metacognitive learning strategies at an adequate age and adequate level of cognitive abilities of students are the assumption of financial literacy and entrepreneurship support. Using activating teaching methods through the implementation of the case study method is more successful and effective in the development of higher-order thinking operations than the established traditional methods, which are still nowadays overused by teachers. This means that methods have a significant impact on the development of higher cognitive dimensions, which are the fundamental assumption of a successful career for economists and corporate managers. The development of these competencies strengthens the competitiveness of this profession in the labour market.
\end{abstract}

Keywords: business finance, entrepreneurship, competitiveness, competence, cognitive dimension, metacognitive strategies, case study

JEL Classification: A22, A23, M53, M59

Received: May, 2018

1st Revision: July, 2018

Accepted: July, 2018 


\section{INTRODUCTION}

This empirical study is aimed at exploring the development of lower and higher-order thinking processes of students aged 16-17 through the gradual inclusion of a case study method simulating the economic problems of an enterprise into the teaching of economic subjects in secondary education in the Czech Republic. The research is based on the experimental verification of a case study in comparison with usual practices of Czech teachers of economic subjects without using the elements of metacognitive strategies. Metacognitive strategies, however, allow the development of financial and entrepreneurial aspects of learning to create professional competencies in higher cognitive dimensions such as application, analysis, and evaluation. These strategies make it possible to prepare graduates in practice in line with trends in the application sphere. Therefore, they strengthen not only their competitiveness but also secondary schools in the secondary education market (Kim \& Regh, 2018; Savenkova \& Olesina, 2018). A case study as a typical representative of the activation element in the learning process, in theory, seems to be ideal for the use of metacognitive strategies. The authors aim to verify the effective use of the metacognitive strategy and the relevant dependence in relation to the target group of learners and in relation to the teaching style, which the learners are exposed to by teachers, especially the predominant monological teaching methods. The preferred methods of teaching in the Czech educational area are subjected to a long-term and relatively harsh criticism of didactical materialism, so-called encyclopaedism, forced memorization, and a marked predominance of monological teaching methods in the teachers' methodological portfolio, in which learning activation elements are negligible. In this management strategy of a learning process, only the lower layers of the cognitive dimension are developed, and the effect of metacognitive learning strategies is virtually avoided. This study examines these contexts.

\section{THEORETICAL BACKGROUND}

\subsection{Case studies and implications for best practice in Entrepreneurship and Finance Education}

Transformative changes are happening worldwide in entrepreneurship and financial education at all educational levels. These changes are conceptual as well as technological due to the upheaval in the global, social, political and technological environments (Welsh, 2016). The international financial and economic crisis in 2008 produced a new economic era with significant implications for education as a key tool for development of the competences needed for new business creation (Rodrigues et al., 2012). Financial capability plays an important role in entrepreneurial success, so there is a strong link between financial and entrepreneurship education - the learning outcomes are intertwined and related competences and skills largely aligned.

A number of studies have concluded the importance of teaching entrepreneurial skills at an early age, preferably as early as at primary and secondary schools (Obschonka et al., 2011; Rosendahl Huber et al., 2012). This approach ensures progression of the learning outcomes throughout the student's education pathway and fosters a higher and steadier long-term impact. Within this time frame, the focus of entrepreneurship education shifts away from influencing values and attitudes (awareness) to teaching entrepreneurial qualities at a more practical level (readiness) (Kuip \& Verhuel, 2003). 
Entrepreneurship education is seen as an effort by educators to positively affect students' motivations and attitudes towards entrepreneurship and therefore to help develop skills important for being successful in business in the fields for which they are professionally trained. The issue of entrepreneurship education should therefore be adequately reflected in the curriculums of training programmes, teaching methods and competency models (Krpálek \& Krpálková, 2016).

While it is generally acknowledged that many aspects of entrepreneurship can be taught, authors differ in their opinions about the appropriate methods to teach and equip students with the requisite entrepreneurial skills. Several European programmes have been identified as best practices, and were presented at the Oslo Conference, "Entrepreneurship Education in Europe: Fostering Entrepreneurial Mindsets through Education and Learning." In general, the updated teaching programmes encourage critical thinking, creative thinking, communication, researchquestioning and problem solving (e.g., Rahman et al., 2015) and frequently involve interactive and collaborative on-line tools (e-learning, mobile devices and learning networks) (Ventura \& María José, 2013; Churchill, 2009; Yang, 2009, Collins \& Halverson, 2010). The Spanish student company programme "European Young Enterprise" (targeted at youngsters from 14 to 16 years old) includes the creation of a mini-company with real business, customers (preferentially from another country) and money (Rodrigues et al., 2008). This kind of entrepreneurial experience is also an effective way to teach financial education, as it provides the context and possibility for the students to apply their knowledge in a particular case of interest to them.

Another example of best practice is a large scale financial education programme "MoneyIQ" in Romania which includes cooperation with professionals from business and banking sector providing students with different role models and mentorship. The interaction with the business community allows the students to gain sound understanding of real life situations exploring on how these persons manage their finances, how they budget both in personal and professional context, and how important it is to plan for the future. The digital component of "MoneyIQ" includes online training, case studies and a series of online activities and exercises that help teachers deliver financial content (JA Europe, 2016).

The Project "I Can Manage My Money" is a financial education programme targeting young people aged 15 to 30 in Turkey. Face-to-face training sessions and peer-based education are the core elements of the project. Through this education model, young people from a similar age group, background, culture and social status educate each other about financial literacy. One of the main advantages of this model relies on strong connections built between trainer and trainees. Learning from someone who has the same level of income, speaks the same language, and potentially faces or will face in the near future similar financial problems makes the learning process more credible and real. In 2013, online training sessions were developed and are available on the project's website (JA Europe, 2016).

\subsection{Financial literacy and survey PISA}

Measuring the level of financial literacy among students under the PISA 2012 international survey (OECD, 2014) focuses on four content categories (1 - Money and Transactions; 2 - Planning and Management of Finances; 3 - Risk and Reward; 4 - Financial Landscape). A total of 18 countries worldwide took part in the survey, with 288 schools, i.e. 1,207 students, participating 
in the Czech Republic. Czech pupils ranked among the 6 countries with above-average results (the others were Belgium, Estonia, Australia, New Zealand and the Municipality of Shanghai) (Berková \& Krpálek, 2017).

For our research, the study Category No. 2 is of key importance as it relates to the issue of asset and capital structure management. Czech pupils have achieved 513 points and are ranked sixth among the tested countries. Considering the OECD average of 505 points, this result can be considered above average. Despite of this result, according to many business organizations, the development of educational activities and counselling obviously lags behind the needs of the business sector, small and medium-sized enterprises in particular. A serious problem is the perceived lack of communication between schools that prepare graduates for practice and the business sphere. For doing business, any state has to create conditions, but also entrepreneurs themselves have to meet certain conditions or assumptions (OECD, 2014).

The authors Kaiser \& Menkhoff (2017) in a meta-analysis of 126 Impact Assessments studies found that financial education has a significant impact on financial behaviour and, to an even greater extent, on financial literacy. Intervening impacts were very heterogeneous: financial education is less effective for low-income clients as well as for low-income and low-income economies. Improving financial literacy also has an indirect positive impact on financial behaviour, although this indirect effect is small, so changes in financial behaviour should be addressed directly. The impacts on financial behaviour are higher if the intensity of education increases and financial education is offered when it is possible to learn.

Over the past decade, the Australian Securities and Investment Commission has led various policy initiatives and has influenced the development of curricula and resources in this area. However, there remains a lack of research that explores how Australian teachers give meaning to their teaching staff in the area of financial literacy and vocational learning needs and interests in this interdisciplinary field. The authors of Sawatzki \& Sullivan (2017) conducted a research focusing on the practical teaching of teachers about the possibilities of teaching and learning in the field of financial literacy. The data was collected from 35 teachers in 16 Victorian primary schools. The findings indicate the need to educate teachers to think about the knowledge, skills and abilities needed to make informed financial decisions to identify and interpret the possibilities of teaching and learning in the field of financial literacy and to adopt sophisticated pedagogical practice. It was found that more than $75 \%$ of teachers agreed or definitely agreed to be financially literate, but only half of them said they were convinced of teaching financial literacy. Before the research itself, vast majority signalled an interest in further professional development about teaching of financial literacy. We also agree that teaching and learning in the field of financial literacy of students should be through simulated real-world experience of solving financial problems and decision-making processes in the real world, and if we consider an important decision-making ability, it is necessary to focus on the development of students' critical thinking. The authors of Škoda et al. (2016) have empirically verified the application of this strategy based on the IBSE (a rather frequently applied strategy of directing learning activities in teaching science subjects) in direct teaching at 332 secondary school students for five months. The highest learning outcomes were achieved with students who used active information processing. According to the authors, this result is influenced by the use of metacognitive strategies in the learning system (Berková et al., 2017). 
The development of higher cognitive levels is reflected in the conceptual Higher-Order Cognitive Skills (HOCS) (Zoller, 2015), which represents the gnoseological process of systemic, evaluative, moral thinking and creativity development. For this purpose, several appropriate indicators experimentally verified in the secondary education are used: (a) problem solving; (b) transfer of experience, assumptions of students through experiential learning; (c) problemsolving questions (d) decision-making tasks with the support of moral, creative thinking and thinking skills assessment. The HOCS model is applicable to different levels of education. This research is basically the basic theory for our article, which we have verified in a modified form under conditions of Czech education.

The authors Belás et al. (2016) demonstrate in their empirical research that the intensity of interest in the socio-economic system is relatively low and students are not adequately motivated to be proactive. Therefore, the authors proposed to create more space for the intense use of advanced teaching methods in order to improve application skills of students. In this context, it is necessary to focus on promotion of personal initiative among the students.

\subsection{The importance of developing soft skills for a career}

The development of soft skills and their position on the labour market has gained momentum in the long run and is getting as important as the professional competencies of the employees, as evidenced by several empirical foreign studies which will be further presented in the article (Borghans et al., 2006; Bacolod \& Blum, 2010; Weinberger, 2014).

According to Krpálek \& Krpálková Krelová (2012), competencies can be traced from two perspectives, as key competencies and professional competencies. This term is defined by a number of authors who agree that they are acquired attitudes, knowledge and skills of an individual which are necessary for work performance (Mužík \& Krpálek, 2017; Kessler, 2006; Spencer \& Spencer, 2008; European Commission, 2008, 2007).

It is empirically proved that a higher level of competencies, not only for their productivity but also for their relative rarity, leads to a better position of the individual on the labour market. The effect is mainly reflected in a higher chance for an individual to get a job, a higher wage and a lower risk of his dismissal (Orazem \& Vodopivec, 1997).

The research of Kolářová \& Kolářová (2017) also dealt with questions about the ability to work in a large team, using their own creativity and responsibility for their work. The results show that real-life training sufficiently prepares students for upcoming practice.

The authors Vendolská \& Kačerová (2016) discovered that the criterion employers consider the most important is the flexibility and adaptability of a job candidate. This criterion is followed by willingness to learn, loyalty, and independence. The students consider the most important criteria to be foreign language skills, followed by communication skills, and willingness to learn and an internship during their studies.

The reason for the growing importance of soft competencies is the preference of employers in relation to the development of jobs. According to the authorship of Borghans et al. (2006), between 1970 and 2002, there was a significant increase in jobseekers whose performance required soft skills significantly. In the period 1977 to 2010, the employment growth was concentrated in occupations that laid requirements for both (financial) and soft skills. 
These findings are also in line with studies by Bacolod \& Blum (2010), who have shown a significant positive correlation between job requirements for individual work positions for professional and soft skills. Soft competencies, in close proximity to professional competencies, have a positive effect on the wage growth of employees who are assessed as successful and competent, in identifying and evaluating work performance.

\section{RESEARCH METHODOLOGY AND DATA ANALYSIS}

The research was carried out in the second half of 2017. The following hypotheses are verified in relation to the objective of the study - exploring the development of thinking operations of lower and higher order through experimental verification by the case study method based on metacognitive strategies in secondary education - the following hypotheses are verified:

H1: For students aged 16, the effects of the case study method in the development of lower-order thinking operations are higher than the effects of established teachers' methods.

H2: For students aged 16, the effects of the case study method in the development of higher-order thinking operations are higher than the effects of established teachers' methods.

H3: For students aged 17, the effects of the case study method in the development of lower-order thinking operations are lower than the effects of established teachers' methods.

H4: For students aged 17, the effects of the case study method in the development of higher-order thinking operations are lower than the effects of established teachers' methods.

The research sample was created by deliberate sampling from two regions of the Czech Republic - the Capital City of Prague and Vysočina. The sample consisted of 220 students - from three secondary schools (business academies), aged 16-17, whose financial competences are developed in traditional economic subjects without the elements of metacognitive strategies and pedagogical constructivism. These schools have been selected for a long-term collaboration with a research team who is very well versed in the ways of teaching and learning strategies in their conditions.

Students aged 16 represent the second year of study at secondary schools under conditions of Czech education. This is the lowest grade when it is possible to start studying all profile economic subjects. Older students aged 17 represent the third grade of high school. We assume that regarding 16-year-old students who start with economic subjects, the development of professional competencies by modern methods is more effective than of older students aged 17 . That is why this age range has been chosen.

Thus, the selected age range is particularly relevant for our research study to measure the effects of the case study method with students starting Business Economics and Accounting (i.e. $41 \%$ of the sample were individuals aged 16) where it is easier to build the basis for developing their financial competencies at the level of lower-order thinking operations (remembering, understanding the curriculum) and at the level of adequate higher-order operations (applying, analysing, or evaluating). For older students (i.e. 59\% of the sample were 17 years old), based on the traditional methods used by teachers, it is possible to assume deeper habits that do not lead to the development of higher-order thinking processes up to the level of creative thinking. Therefore, the implementation of the case study method with older students having these habits may be more problematic. 
The creation of a research sample was also inspired by systematic, internationally recognized research aimed at experimentally verifying the development of higher cognitive dimensions in education (Zoller, 2015). The author has developed a conceptual model of the development of these competencies, which are also subject to our verification in the conditions of Czech education. Due to the fact that the author researched younger and older students of similar age, students of this age category were selected for the research sample.

The research sample is closely monitored in the data analysis for the purpose of experimental verification of the development of lower and higher order thinking processes, according to experimental and control groups (Tab. 1). In each group, older students predominate, due to the current status of students at secondary schools where the research was conducted. Nevertheless, the students were selected according to the pedagogical research method into the experimental and control group, the experimental group representing the students with lower results from economic subjects (average school grade from the previous school year 2.7) and the control group with higher results (the average school grade of the previous school year 2.1).

Tab. 1 - The structure of the Research Sample. Source: authors' research

\begin{tabular}{|l|l|l|l|l|}
\hline \multirow{2}{*}{$\begin{array}{l}\text { Age of the } \\
\text { Student }\end{array}$} & Experimental Group & Control Group \\
\cline { 2 - 5 } & Absolutely & Relatively & Absolutely & Relatively \\
\hline 16 years old & 43 & $39.8 \%$ & 47 & $41.9 \%$ \\
\hline 17 years old & 65 & $60.2 \%$ & 65 & $58.1 \%$ \\
\hline Total & 108 & $100 \%$ & 112 & $100 \%$ \\
\hline
\end{tabular}

The experiment was chosen as the basic research method. Relevant research tools have been developed in several series to support the method:

a) A learning case study was adapted to each age group of students with a focus on relevant learning content. The learning case studies were a live story with problem solving elements, studies included tasks with an emphasis on the development of higher-order thinking processes - application, analysis (Anderson et al., 2001). Table 2 also emphasizes the development of soft competencies - particularly communication, presentation and argumentation skills. For students beginning with the studies of economic subjects at the age of 16, case studies were created in a simpler form of decision-making, according to the Methodology of Fortmüller \& Konczer (2013), which allows the development of thinking-based operations to the level of application, which is adequate to the students' initial knowledge and skills. For older students with more developed financial competencies, the case study was designed to develop financial competences at the level of higher-order thinking processes (application, analysis). Case studies were implemented into an experimental age group of students, each study containing a different topic. These studies were prepared for 4 teaching hours. This length was adequate to the selected educational content. The same topics were discussed in the control groups, but with the help of examples designed according to the established traditional teaching practices, which do not reflect metacognitive strategies and thus do not allow the development of higher-thinking processes. The learning case study was created by a research team and implemented in teaching through secondary-school teachers. 
b) The second set of research tools was represented by a non-standardized post-test, which was uniformly designed for the experimental and control group to determine the range of effects at the level of development of lower and higher-order thinking processes, which the implemented methods can bring. According to the methodology of pedagogical research, the pre-test can be omitted and included only post-test. In our case, we were inspired by this because the starting point for comparing the performance was the school performance of students in economic subjects. In total, two post-tests were developed based on the classification of students in the respective study years which varied in the content and cognitive difficulty. For each assignment, students expressed the degree of certainty of their answer at the scale of 1 ranking the lowest score to the 5 ranking the highest score. The educational content, which was the core of the experiment and the post-test, is shown in Tab. 2 broken down by the age of students. The main topic of the experiment with 16-year-old students was starting the business and the impact on the company's capital and capital structure. The topic of students at the age of 17 was inventory valuation and the impact of inventory valuation methods on the company's economic activities.

Tab. 2 - The Content of Experimental Teaching. Source: authors' research

\begin{tabular}{|l|l|}
\hline $\begin{array}{l}\text { Cognitive Process } \\
\text { Dimension }\end{array}$ & Educational Content \\
\hline $\begin{array}{l}\text { Remember (lower } \\
\text { order thinking) }\end{array}$ & $\begin{array}{l}\text { Aged 16: (1) Enterprise assets and capital; (2) balance sheet, informa- } \\
\text { tion on the financial situation; } \\
\text { Aged 17: (a) inventory characteristics; (b) terminology; }\end{array}$ \\
\hline $\begin{array}{l}\text { Understand (lower } \\
\text { order thinking) }\end{array}$ & $\begin{array}{l}\text { Aged 16: (3) balance sheet principle; (4) the impact of transactions on } \\
\text { the display of balance sheet items; } \\
\text { Aged 17: (c) displaying of transactions with respect to the purchase of } \\
\text { stock in the accounting and in-house operations; }\end{array}$ \\
\hline $\begin{array}{l}\text { Apply (higher order } \\
\text { thinking) }\end{array}$ & $\begin{array}{l}\text { Aged 16: (5) the effect of transactions on the profit or loss of the } \\
\text { company; }\end{array}$ \\
\hline $\begin{array}{l}\text { Aged 17: (d) inventory valuation methods for stockpiling and stock } \\
\text { documentation; }\end{array}$ \\
$\begin{array}{l}\text { Analysis (higher } \\
\text { order thinking) }\end{array}$ & $\begin{array}{l}\text { Aged 16: not assigned. } \\
\text { Aged 17: (e) the analysis of company's results on the basis of realized } \\
\text { transactions. }\end{array}$ \\
\hline
\end{tabular}

The data was analyzed with the support of the NCSS statistical program (Hintze, 2007, NCSS and PASS, Kaysville, Utah). To verify zero hypotheses at 5\%, a non-parametric Mann-Whitney u-test was chosen to measure the differences between the outputs of the two sample sets. This test was selected because of the structuring to two independent samplings (i.e. experimental and control group) and because of not proving normality of data at 5\% (i.e. Kolmogorov-Smirn test, $\mathrm{P}=0.1824$ ). For both samplings, the sum of the order is created and the lesser of the two totals is compared to the critical test value. If this value is less than the critical value of the test, we reject the zero hypothesis that claims no match or difference between samplings. Zero hypotheses and alternative hypotheses are formulated as follows: 
HO-1: $\beta i=0$

There is no difference in effects of the case study method and the established methods of teachers in the development of lower-order thinking processes for students aged 16.

H1-1: non HO-1

HO-2: $\beta i=0$

There is no difference in effects of the case study method and the established methods of teachers in the development of higher-order thinking processes for students aged 16.

H1-2: non HO-2

HO-3: $\beta i=0$

There is no difference in effects of the case study method and the established methods of teachers in the development of lower-order thinking processes for students aged 17.

H1-3: non $\mathrm{HO}-3$

HO- $4: \beta i=0$

There is no difference in effects of the case study method and the established methods of teachers in the development of higher-order thinking processes for students aged 17.

H1-4: non HO-4

\section{RESEARCH RESULTS}

The first research probe oriented on experimental verification of the effects of the applied case study method with elements of metacognitive strategies in the teaching of economic subjects in comparison with the established traditional methods of teachers shows several basic prerequisites for the possibility of building financial competences. The research was conducted in two series:

a) for students starting with economic subjects at the age of 16 ,

b) for older students with deeper habits based on the established school methodology at the age of 17 .

For students starting their economic studies and acquiring basic knowledge of business with financial aspects, the implementation of case study method is more successful and efficient in the area of development of higher-order thinking (application) compared to the traditional established methods which teachers use in the current education system with $95 \%$ reliability of the u-test. The case study method is more effective with younger students than older students with deeper habits to the study system as well (illustrated in Tab. 3 - 4). 
Tab. 3 - Differences between independent samplings H0-2; H0-4 - analysis of the development of higher order thinking processes for students aged 16 and 17. Source: authors' research

\begin{tabular}{|l|l|l|l|l|l|}
\hline \multirow{2}{*}{$\begin{array}{l}\text { Student's cognitive level } \\
\text { (age) }\end{array}$} & \multirow{2}{*}{$\mathrm{N}$} & Apply & Analysis \\
\cline { 3 - 6 } & & Prob Level & $\begin{array}{l}\text { Reject H0 } \\
\text { at 5\% }\end{array}$ & Prob Level & $\begin{array}{l}\text { Reject H0 } \\
\text { at 5\% }\end{array}$ \\
\hline 16 years old & 90 & 0.026798 & Yes & not analyzed & $\begin{array}{l}\text { not ana- } \\
\text { lyzed }\end{array}$ \\
\hline 17 years old & 130 & 0.854934 & No & 0.578765 & No \\
\hline
\end{tabular}

Tab. 4 - Relative performance between independent student-based samplings - analysis of the development of higher-order thinking processes. Source: Authors' Research

\begin{tabular}{|c|c|c|c|c|}
\hline \multirow[b]{2}{*}{$\begin{array}{l}\text { Student's } \\
\text { cognitive } \\
\text { level (age) }\end{array}$} & \multicolumn{2}{|c|}{ Experimental Group } & \multicolumn{2}{|l|}{ Control Group } \\
\hline & $\begin{array}{l}\text { Performance in } \\
\text { the Apply Dimen- } \\
\text { sion }\end{array}$ & $\begin{array}{l}\text { Performance } \\
\text { in the Analysis } \\
\text { Dimension }\end{array}$ & $\begin{array}{l}\text { Performance in } \\
\text { the Apply Dimen- } \\
\text { sion }\end{array}$ & $\begin{array}{l}\text { Performance } \\
\text { in the Analysis } \\
\text { Dimension }\end{array}$ \\
\hline 16 years old & 0.647 & - & 0.534 & - \\
\hline 17 years old & 0.564 & 0.118 & 0.564 & 0.169 \\
\hline
\end{tabular}

With $95 \%$ reliability of the test, there are differences in the development of higher-order thinking operations using the case study method and established traditional teaching methods for 16year-old students starting with the economic studies $(\mathrm{P}=0.026798)$. We dismiss the $\mathbf{H} \mathbf{0}-\mathbf{2}$ hypothesis at the $5 \%$ significance level. The case study method brings higher effects. With $95 \%$ reliability of the test, there are no differences in the development of higher-order thinking operations using the case study method and established traditional teaching methods for students aged $17(\mathrm{P}=0.854934, \mathrm{P}=0.578765)$. We do not dismiss the $\mathbf{H 0}-4$ hypothesis at the $\mathbf{5 \%}$ significance. This trend points to the first prerequisite for building financial competences in the field of business economics - namely that in education, it is necessary to use metacognitive learning strategies adequately to the age and skills of students and to guide students in the early stages of economic education to develop higher-order thinking operations in a consistent manner. At higher levels of studies, if prerequisites have not been created, this development can be difficult to support.

Since the case studies contained elements of metacognitive strategies with an emphasis on awareness and development of one's own higher-order thinking processes, 95\% reliability of the u-test did not show statistical differences between the application of the case study method and the established school methods, both age groups of students. However, in case of students who start with the studies of economic subjects (aged 16), the case study method has been proved more successful than established methods of teachers. The experimental group has achieved better results, although statistically significant differences between the experimental and the control group at the 5\% significance have not been demonstrated (illustrated in Tab. 5 - 6). 
Tab. 5 - Differences between independent samplings H0-1; H0-3 - analysis of the development of lower-order thinking operations for students aged 16 and 17. Source: authors' research

\begin{tabular}{|l|l|l|l|l|}
\hline \multirow{2}{*}{$\begin{array}{l}\text { Student's cognitive level } \\
\text { (age) }\end{array}$} & \multicolumn{2}{|l|}{ Remember } & \multicolumn{2}{l|}{ Understand } \\
\cline { 2 - 5 } & Prob Level & Reject H0 at 5\% & Prob Level & Reject H0 at 5\% \\
\hline 16 years old & 0.522328 & No & 0.671707 & No \\
\hline 17 years old & 0.980003 & No & 0.346814 & No \\
\hline
\end{tabular}

Tab. 6 - Relative performance between independent samplings based on age - analysis of lower-order thinking development. Source: authors' research

\begin{tabular}{|c|c|c|c|c|}
\hline \multirow[b]{2}{*}{$\begin{array}{l}\text { Student's cogni- } \\
\text { tive level (age) }\end{array}$} & \multicolumn{2}{|c|}{ Experimental Group } & \multicolumn{2}{|l|}{ Control Group } \\
\hline & $\begin{array}{l}\text { Performance } \\
\text { in Remember } \\
\text { Dimension }\end{array}$ & $\begin{array}{l}\text { Performance } \\
\text { in Understand } \\
\text { Dimension }\end{array}$ & $\begin{array}{l}\text { Performance } \\
\text { in Remember } \\
\text { Dimension }\end{array}$ & $\begin{array}{l}\text { Performance } \\
\text { in Understand } \\
\text { Dimension }\end{array}$ \\
\hline 16 years old & 0.581 & 0.878 & 0.537 & 0.805 \\
\hline 17 years old & 0.815 & 0.804 & 0.792 & 0.805 \\
\hline
\end{tabular}

With $95 \%$ reliability of the test, there are no differences in the development of lower-order thinking processes using the case study method and established traditional teaching methods for 16-year-old students starting with the economic studies ( $\mathrm{P}=0.522328 ; 0.671707)$. We do not oppose the H0-1 hypothesis at the 5\% significance. With $95 \%$ reliability of the test, there are no differences in the development of lower order thinking operations using the case study method and established traditional teaching methods for students aged $17(\mathrm{P}=0.980003, \mathrm{P}=$ 0.346814). We do not oppose the hypothesis $\mathbf{H 0 - 3}$ at the $\mathbf{5 \%}$ significance level. An important factor in evaluating the effect of the case study method in comparison with the established teaching methods is not only the point score that students received in the post-test, i.e. the students' success in individual dimensions of cognitive process of lower and higher order, but also the degree of certainty in their responses.

Examining the implemented method according to the degree of student's confidence in individual cognitive dimensions is not the main objective of our study, but it is also necessary to link these results with the development of score measured by the point score in the experiment. For the case study group, the confidence level was higher in tasks with metacognitive elements - higher order operations (application, analysis), up to 7\%, which is true for students aged 17. For students aged 16, there is a convergence of certainty for tasks with lower and higher order operations, with a difference of only $0.3 \%$. Students from the experimental group were the most confident ones in the most challenging task in terms of cognitive dimensions, in analysing business performance (Tab. 7). 
Tab. 7 - The degree of confidence of students in cognitive dimensions of lower and higher order in case study method implementation (in \%). Source: authors' research

\begin{tabular}{|c|c|c|c|c|c|c|}
\hline 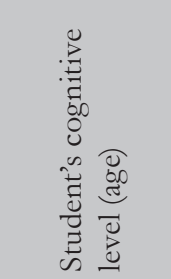 & 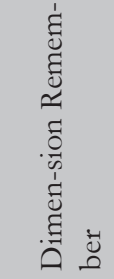 & 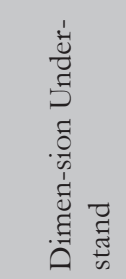 & 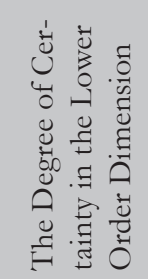 & 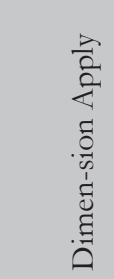 & 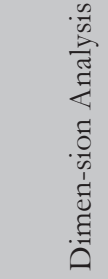 & 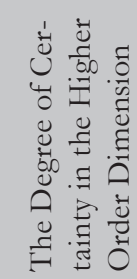 \\
\hline 16 years old & $17.8 \%$ & $21.6 \%$ & $19.7 \%$ & $20 \%$ & - & $20 \%$ \\
\hline 17 years old & $34.3 \%$ & $33.4 \%$ & $33.9 \%$ & $27.1 \%$ & $53 \%$ & $40 \%$ \\
\hline
\end{tabular}

In the group taught by established traditional teaching methods, the degree of certainty was lower not only in tasks with meta-cognitive elements - higher order operations (application, analysis) but also in tasks focusing only on memorizing and understanding the curriculum (Tab. 8). There are not significant differences, but still advantages of the method become apparent - developing of higher-order thinking operations and also creating a higher degree of certainty in students' responses, which can also have a desirable effect on the development of soft competencies.

Tab. 8 - The degree of certainty of students in the dimensions of cognitive process of lower and higher order using traditional teaching methods (in \%). Source: authors' research

\begin{tabular}{|c|c|c|c|c|c|c|}
\hline 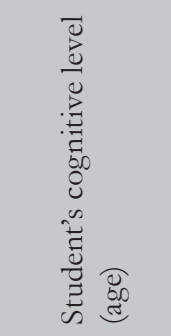 & 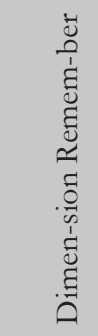 & 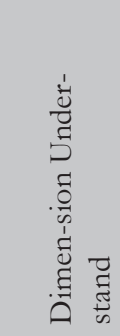 & 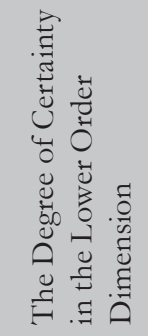 & 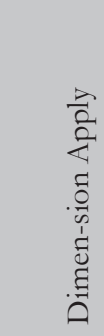 & 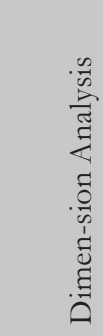 & 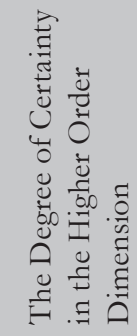 \\
\hline 16 years old & $15.7 \%$ & $19.1 \%$ & $17.4 \%$ & $14.3 \%$ & - & $14.3 \%$ \\
\hline 17 years old & $35.4 \%$ & $33.2 \%$ & $34.3 \%$ & $20.5 \%$ & $43.9 \%$ & $32.2 \%$ \\
\hline
\end{tabular}

\section{DISCUSSION AND CONCLUSIONS}

The analysis of the empirical research results has shown how style of teaching has a significant impact on the level of competencies achieved in the initial stages of education. The key research tool - experiment - dealing with economic education, was focused on the area of business economics, finance, financial literacy, entrepreneurship and creativity, that is, it dealt with cross-sectoral spheres of professional and key competencies. The intention was to examine the reflection of current pedagogy residing in the fact that if students from the very beginning of formal economic education are guided by conventional non-activating teaching styles, based on the monological delivery of the completed educational contents and without developing their 
autonomy and creativity, and if attention to key competences remains aside, they gain a tendency to passivity, and they show resistance to activating teaching methods that could eventually be applied by teachers in their further education. Then, preferred learning styles are deformed and their competences to learn and self-responsible learning are limited (cf., Obschonka et al. , 2011; Rosendahl Huber et al., 2012, who also demonstrated the importance of the development of entrepreneurial skills at an early age starting at primary education, Kuip \& Verhuel, 2003).

For students who start with economic education - those who get their first knowledge of business together with the primary financial aspects of management and entrepreneurship - the experiment has proved that activation of teaching through the implementation of the case study method is more successful and more effective in the area of development of higher order thinking operations (application and higher cognitive domains) compared to established traditional methods (predominance of monological teaching methods), which are still overused by teachers. Experimental case-based learning has proved to be more effective with younger students than older students with deeper learning habits, as these students are used to memorizing completed educational contents without the need to cooperate and participate actively in their own learning. The higher the order thinking operation, the more this is true. The differences disappear at the lowest level of thinking operations (remembering, understanding), as being partly covered by the monologue style of teaching (in the traditional teaching style). The following is a summary of the research hypothesis review results (Tab. 9).

Tab. 9 - Verification of research hypotheses. Source: authors' research

\begin{tabular}{|l|l|}
\hline Research hypotheses & Rejected/Accepted \\
\hline $\begin{array}{l}\text { H1: For students aged 16, the effects of the case study method in the } \\
\text { development of lower order thinking operations are higher than the } \\
\text { effects of established teachers' methods. }\end{array}$ & Rejected \\
\hline $\begin{array}{l}\text { H2: For students aged 16, the effects of the case study method in } \\
\text { the development of higher order thinking operations are higher } \\
\text { than the effects of established teachers' methods. }\end{array}$ & Accepted \\
\hline $\begin{array}{l}\text { H3: For students aged 17, the effects of the case study method in the } \\
\text { development of lower-order thinking operations are lower than the } \\
\text { effects of established teachers' methods. }\end{array}$ & Rejected \\
\hline $\begin{array}{l}\text { H4: For students aged 17, the effects of the case study method in the } \\
\text { development of higher order thinking operations are lower than the } \\
\text { effects of established teachers' methods. }\end{array}$ & Rejected \\
\hline
\end{tabular}

In any case, the activation of teaching and the application of case studies have proved to be empirical, although we must be cautious in the view of an exact statistical evaluation of the experiment. Despite the structure of the research sample and the number of students, anyone can be inspired by foreign teaching elements and tools that are more sophisticated and conducive to the desired cognitive goals. These are educational programmes that support critical and creative thinking, communication and problem solving (Rahman et al., 2015), interactive e-learning tools, mobile devices and learning (Ventura \& María José, 2013; Churchill, 2009, Yang, 2009; 
Zoller, 2015; Collins \& Halverson, 2010), and the Spanish student company program "European Young Enterprise" (Rodrigues et al., 2008). These tools and forms of education have been gradually penetrating the Czech education system, but not to such an extent as would be necessary for the formation of entrepreneurial spirit. By not showing the effects of a case study method with older students, it can be assumed that the conventional non-activating teaching style is still used by teachers. These findings suggest, similarly to Sawatzki \& Sullivan (2017), the need to educate teachers to think about the knowledge, skills and competences needed to be able to make an informed financial decision with the aim to identify and interpret the possibilities of teaching and learning in the area of financial literacy.

Interestingly, in the group of students aged 17 with the experimental teaching based on case studies, a higher degree of certainty has been identified in tasks with metacognitive elements (higher order operations, application, analysis) compared to a group taught by traditional lessonbased methods, where the degree of certainty was lower - not only in tasks with metacognitive elements, but also in tasks focusing only on memorizing and understanding the curriculum. Although there are small differences, however, it is possible to demonstrate the advantages of an activating method that develops higher order thinking operations and supports higher confidence in responses as well as the development of soft competencies. It is the development of soft competencies that is not aimed at by the teachers and goes hand in hand with the development of professional competencies. Applying metacognitive learning strategies is all the more important as it makes it possible to effectively develop soft (key) competencies that are relevant to economic practices (Bacolod \& Blum, 2010).

This context points to the fact that the application of metacognitive learning strategies adequate to the age and the acquired level of cognitive abilities of students is the prerequisite for creating financial literacy and promoting entrepreneurship. Students need to be motivated and led consistently to the development of higher order thinking processes from the early stages of economic education. At the same time, the curriculum must be horizontally and vertically integrated, that is, the knowledge of different subjects (disciplines) must be linked in application to the real economy and to economic practices. Teaching must be conducted in an activating way, students must be drawn into the learning process, students themselves must be willing to learn, and they have to participate in the process actively. This way of education strengthens the competitiveness of future graduates in the labour market.

\section{ACKNOWLEDGMENTS}

This research was supported by the external scientific project of the Grant Agency of Academic Alliance, "The Factor of Finance and Entrepreneurship in Terms of Human Capital Development" (2018), and by the Internal Grant Agency of the University of Economics in Prague, No. F1/31/2015, and it is part of a project of the Faculty of Finance and Accounting carried out with the help of institutional support from the University of Economics in Prague, No. IP 100040.

\section{References}

1. Anderson, L. W., Krathwohl, D. R. et al. (2001). A Taxonomy for Learning, Teaching and Assessing. A Revision of Bloom's Taxonomy of Educational Objectives. New York: Longman.

2. Bacolod, M., \& Blum, B. S. (2010). Two sides of the same coin: U.S. „residual” inequality and the gender gap. Journal of Human Resources, 45 (1), 197-242. 
3. Belás, J., Nguyen, A., Smrčka, L., Kolembus, J., \& Cipovová, E. (2016). Financial Literacy of Secondary School Students. Case Study from the Czech Republic and Slovakia. Economics and Sociology, 9 (4), 191-206. https://doi.org/10.14254/2071-789X.2016/9-4/12

4. Berková, K., \& Krpálek, P. (2017). Approaches to the development of cognitive process dimensions in financial literacy: an empirical study. Journal of International Studies, 10 (3), 173 188. https://doi.org/10.14254/2071-8330.2017/10-3/13

5. Berková, K., Králová, A., \& Krejčová, K. (2017). Application of the Metacognitive Strategy in Economic Education in the Czech Republic. The Turkish Online Journal of Educational Technology, October Special Issue for INTE 2017, 373-380.

6. Borghans, L., Weel, B. Ter, \& Weinberg, B. A. (2006). People People: Social capital and the labormarket outcomes of underrepresented groups. Working paper No. 11985.

7. Collins, A., \& Halverson, R. (2010). The second educational revolution: Rethinking education in the age of technology. Journal of Computer Assisted Learning, 26 (1), 18-27.

8. European Commission.(2008). The European Qualifications Framework for Lifelong Learning (EQF). Luxembourg: Office for Official Publications of the European Communities.

9. European Commission. (2007). The Key Competences for Lifelong Learning - A European Framework. Luxembourg: Office for Official Publications of the European Communities.

10. Fortmüller, R., \& Konczer, K. (2013). Didaktische Grundsätze des Rechnungswesenunterrichts. In: Aff, J., \& Fortmüller, R. (Eds.) Entrepreneurship - Erziehung im Wissenschaftlichen Diskurs, Wien: MANZ.

11. Churchill, D. (2009). Educational applications of Web 2.0: Using blogs to support teaching and learning. British Journal of Educational Technology, 40 (1), 179-183. https://doi.org/10.1111/ j.1467-8535.2008.00865.x

12. JA Europe (2016). Sharpening financial education: How the right partnerships can hone the skills of tomorrow's entrepreneurs and employees. Retrieved from: http://www.eesc.europa. eu/resources/docs/ja-europe_sharpening-financial-education-report.pdf (30.11.2017).

13. Kaiser, T., \& Menkhoff, L. (2017). Does Financial Education Impact Financial Literacy and Financial Behavior, and If So, When? Rationality and Competition. Retrieved from: https:// rationality-and-competition.de/wp-content/uploads/discussion_paper/37.pdf (12.12.2017).

14. Kessler, R. (2006). Competency-Based Interviews. Franklin Lakes: Career Press.

15. Kim, H., \& Rehg, M. (2018). Faculty Performance and Morale in Higher Education: A Systems Approach. Systems Research and Behavioral Science, 35 (3), 308-323. https://doi. org $/ 10.1002 /$ sres. 2495

16. Kolářová E., \& Kolářová V. (2017). Influencing college students’ choice of elective subjects. Journal of Competitiveness, 9 (4), 40-49. https://doi.org/10.7441/joc.2017.04.03

17. Krpálek, P., \& Krpálková Krelová, K. (2012). Didaktika ekonomických prèdmètů (Didactics of Economic Subjects), Prague: Oeconomica.

18. Krpálek, P., \& Krpálková Krelová, K. (2016). Developing business potential in economic education. Examples of implementation in Slovakia and the Czech Republic. Economics and Sociology, 9 (4), 119-133. https://doi.org/10.14254/2071-789X.2016/9-4/7 
19. Mužík, J., \& Krpálek, P. (2017). Lidské zdroje a personálni management (Human Resources and Personal Management). Prague: Academia.

20. Obschonka, M., Silbereisen, R.K., Schmitt-Rodermund, \& Stuetzer, M. (2011). Nascent entrepreneurship and the developing individual: Early entrepreneurial competence in adolescence and venture creation success during the career. Journal of Vocational Behavior, 79 (1), 121-133. https://doi.org/10.1016/j.jvb.2010.12.005

21. OECD (2014). PISA 2012 Results: Students and Money: Financial Literacy Skills for the 21st Century (Volume VI), PISA, OECD Publishing. Retrieved from: http://dx.doi.org/10.1787/ 9789264208094-en (26.10.2017)

22. Orazem, P. F., \& Vodopivec, M. (1997). Value of human capital in transitiv to market: Evidence from Slovenia. European Economic Review, 41 (3-5), 893-903.

23. Rahman, S., Yasin, R. M., Buang, N., Oganisjana, K., Fernate A., \& Koke, T. (2015). Using problem-focused approach to nurture creativity and entrepreneurship among students. Procedia - Social and Behavioral Sciences, 191, 2782-2786. https://doi.org/10.1016/j.sbspro.2015.04.628

24. Rodrigues, R.G., Dinis, A., Arminda, Paço, A., Ferreira, J., \& Raposo, M. (2012). The effect of an entrepreneurial training programme on entrepreneurial traits and intention of secondary students. In: Burger-Helmchen, T. (Ed.), Entrepreneurship - born, made and educated, Rijeka, Croatia: InTech.

25. Rosendahl Huber, L., Sloof, R., \& van Praag, M. (2012). The Effect of Early Entrepreneurship Education: Evidence from a Randomized Field Experiment. Tinbergen Institute Discussion Paper TI 2012-041/3.

26. Savenkova, L. G., \& Olesina, E. P. (2018). Strategic Planning as a Factor of Improvement of Contemporary Education Quality Management. Quality, 19 (164), 82-87.

27. Sawatzki, C., \& Sullivan, P. (2017). Teachers' Perceptions of Financial Literacy and the Implications for Professional Learning. Australian Journal of Teacher Education, 42 (5). https:// doi.org/10.14221/ajte.2017v42n5.4

28. Spencer, L. M., \& Spencer, S. M. (2008). Competence at Work - Models for Superior Performance. New York: Wiley.

29. Škoda, J., Doulík, P., Bílek, M., \& Šimonová, I. (2016). Learning style as a factor influencing the effectiveness of the inquiry-based science education at lower secondary schools. Journal of Baltic Science Education. 15 (5), 588-601.

30. Van De Kuip, I., \& Verheul, I. (2003). Early development of Entrepreneurial Qualities: The role of initial education. SCALES paper series.

31. Vendolská I., \& Kačerová E. (2016). Flexible Graduate is Successful Graduate. Key Factors of Successful Job Interview, Results of a Comparative Analysis. Journal of Competitiveness, 8 (2), 87-102. https://doi.org/10.7441/joc.2016.02.07

32. Ventura, R., \& María José, Q. (2013). Collaborative learning and interdisciplinarity applied to teaching entrepreneurship. Procedia - Social and Behavioral Studies, 93(1), 1510-1515. https://doi. org/10.1016/j.sbspro.2013.10.073

33. Weinberger, C. (2014). The increasing complementarity between cognitive and social skills. The Review of Economics and Statistics, 96(5), 849-861. 
34. Welsh, H. B., Tullar, W. L., \& Nemati, H. (2016). Entrepreneurship education: Process, method or both? Journal of innovation and knowledge, 1(2016), 125-132.

35. Yang, S.H. (2009). Using blogs to enhance critical reflection and community of practice. Educational Technology \& Society, 12 (2), 11-21.

36. Zoller, U. (2015). Research-based transformative science/STEM/STES/STESEP education for "sustainability thinking": From teaching to "know" to learning to "think". Sustainability, 7 (4), 4474-4491. https://doi.org/10.3390/su7044474

\section{Contact information}

assoc. Prof. Dipl. Ing. Pavel Krpalek, Ph.D.

University College of Business in Prague

Czech Republic

E-mail:krpalek@vso-praba.eu

Dipl. Ing. Katarina Krpalkeova Krelova, PhD.

University of Economics, Prague

Department of Economic Teaching Methodology

Czech Republic

E-mail:katarina.krelova@vse.cz.

Dipl. Ing. Katerina Berkova, Ph.D.

University of Economics, Prague

Department of Economic Teaching Methodology

Czech Republic

E-mail:katerina.berkova@vse.cz. 